\title{
Kedudukan Hak Konsumen dalam Memperoleh Informasi yang Jujur terhadap Produk Makanan dan Minuman
}

\section{Bambang Satriya}

Bambang Satriya; Fakultas Hukum Universitas Merdeka Malang; Jl. Terusan Raya Dieng No. 62-64; Malang; Indonesia.

\section{ARTICLEINFO}

Article history:

Received 2019-07-16

Received in revised form

2019-11-11

Accepted 2019-12-01

Kata kunci:

Hak; Konsumen; Informasi; Kejujuran; Pelanggaran.

\section{Keywords:}

Rights; Consumers; Information; Honesty; Violation.

DOI: https://doi.org/10.26905/

idjch.v10i2.3369.
Corresponding Author:

* Bambang Satriya.

E-mail address: satriyash.mh_p@yahoo.co.id

\section{Abstrak}

Konsumen mempunyai banyak hak yang diatur dalam peraturan perundangundangan di Indonesia. Salah satu haknya adalah hak memperoleh informasi yang jujur terhadap produk yang akan digunakan atau dikonsumsinya. Riset ini jenisnya yuridis normatif dengan pendekatan perundang-undangan dan konsepsional, yang bahan hukumnya berbentuk primer dan sekunder serta tersier. Hasil riset menunjukkan, bahwa proteksi yuridis sebagai eksistensi hak konsumen dalam memperoleh informasi yang jujur atas suatu produk makanan dan minuman yang seharusnya diterimanya ternyata masih menjadi hak yang mahal, karena dalam sejumlah temuan menunjukan kalau banyak pelaku usaha atau produsen baik di tingkat lokal, nasional, maupun global yang melanggar norma-norma yuridis. Konsumen yang kedudukannya sangat kuat secara yuridis, ternyata masih menjadi obyek yang dirugikan atau sekedar dijadikan target untuk mengejar dan memenuhi keuntungan ekonomi sebesar-besarnya. Akibatnya, dari hak informasi yang dilanggar ini, hak konsumen lainnya seperti kesehatan dan keselamatannya otomatis terabaikan. Dalam ranah inilah, konsumen menjadi korban secara berlapis-lapis atau menjadi obyek pelanggaran HAM komulatif.

\section{Abstract}

Consumers have several rights which are arranged in Indonesia's rules of law. One of the rights is the right to honest information towards the products which are going to be used or consumed. This is a juridical normative research implementing rules of law and conceptional approach whose legal materials are primary, secondary, tertiary materials. Results of the research show that juridical protection as an existence of consumers' rights in obtaining honest information towards particular food and beverages they should have had is still an unreachable right. This occurs because 


\section{Jurnal Cakrawala Hukum, Volume 10 No. 2 Desember 2019}

ISSN PRINT 2356-4962 ISSN ONLINE 2598-6538

several findings indicate that many producers or businesses in several levels including local, national, and global violate juridical norms. Consumers whose positions are potential and strong juridically could still become theinjured party or become the target to reach and fulfil the profit as much as possible. As a result, fromthis violated information rights, other consumers' rights such as health and safety are automatically neglected. In this domain, consumers become the casualties or become the object of cumulative human rights violation.

\section{Latar Belakang}

Indonesia ini secara konstitusional memang negara yang didasarkan atas hukum. Normanorma yuridis dalam idealisasinya memang diposisikan sebagai panglima atau supremasi, yang menuntut setiap subyek bangsa ini untuk mematuhinya supaya tidak ada pihak-pihak lain yang dirugikan, sebab secara umum setiap perbuatan yang berkategori pelanggaran berdampak merugikan. Perbuatan merugikan ini seringkali tidak disadarinya, meskipun yang melakukan pelanggaran ini banyak diantaranya yang berasal dari subyek terdidik, mapan secara ekonomi, atau subyek sosial yang berpengaruh.

Salah satu hak yang rawan dilanggar atau dirugikan oleh produsen atau pengusaha-pengusaha makanan dan minuman adalah hak atas kesehatan dan keselamatan hidup manusia. Sepertinya hak ini bukan kebutuhan yang mendasar, sehingga ada kesan kuat kalau pengusahapengusaha, baik itu pengusaha kelas gurita maupun kelas gurem seperti pemilik home industry yang bermodal kecil gampang sekali mengorbankan konsumen atau barangkali tidak tahu jika produk makanan dan minuman yang dipasarkannya ternyata mengandung resiko tidak kecil bagi konsumen.

Masih bisa terbaca sebagai suatu fenomena, bahwa kedudukan konsumen di negeri ini masih layaknya obyek yang dijadikan sebagai target mengeruk keuntungan oleh kalangan pengusaha. Resiko buruk yang kemungkinan menimpa konsumen kurang menjadi prioritas. Konsumen ditem- patkan sebagai obyek membesarkan kepentingan kapitalisme pengusaha, atau bagi pemilik modal kecil, konsumen juga diperlakukannya sebagai korban logis demi mengejar kepentingan (kebutuhan) ekonominya. Dari sinilah yang dulu ditakutkan Aristoteles terjadi, bahwa semakin tinggi penghargaan manusia terhadap kekayaan, maka semakin rendahlah penghargaan manusia terhadap nilai-nilai kesusilaan, kebenaran, dan kejujuran (Wahid, 2017).

Pernyataan filosof itu setidaknya mengingatkan setiap subyek sosial dan ekonomi, bahwa siapapun yang menempatkan target keuntungan ekonomi atau memperkaya diri sebagai kepentingan utama, maka mestilah mengakibatkan adanya sejumlah pihak yang menjadi korbannya. Karena mereka gampang terperosok pada praktik-praktik penghalalan segala cara atau dikenal dengan permisifitas.

Terbukti, sudah demikian sering terjadi kasus keracunan menimpa konsumen akibat mengonsumsi produk makanan atau minuman, khususnya konsumen anak-anak. Misalnya kasus keracunan susu atau minuman jenis lainnya berbentuk kemasan yang pernah menimpa siswa Sekolah Dasar dan siswa Madrasah Ibtidaiyah. Sudah banyak konsumen yang menjadi korban produk makanan dan minuman. Pernah 18 siswa MI Miftahul Ulum, desa Wates Tanjung Kecamatan Wringinanom Gresik keracunan setelah makan Jelly Mutiara tanpa merek dan 62 siswa SD Maung Boyolangu Tulungagung keracunan susu (Harwan, 2016). 


\section{Kedudukan Hak Konsumen dalam Memperoleh Informasi yang Jujur terhadap Produk Makanan dan Minuman \\ Bambang Satriya}

Kasus tersebut menunjukkan bahwa posisi konsumen di Indonesia masih lemah. Produk makanan dan minuman yang beredar di lapangan belum ada jaminan kalau produk itu steril dari kemungkinan zat-zat atau bahan-bahan yang membahayakan kesehatan dan keselamatan konsumen. Produk makanan dan minuman yang beredar di pasaran justru layak dicurigai dan diwaspadai oleh konsumen, sebab jika tidak dicurigai dan diwaspadai dikhawatirkan, kalangan produsen akan bertindak merajalela dan sepertinya konsumen identik menjadi obyek pasip pasrah yang menerima setiap produk yang dikonsumsinya 2 .

\section{Metode}

Jenis penelitian yang dipilih adalah penelitian hukum normatif. Penelitian hukum ini mencakup penelitian terhadap asas-asas hukum, sistematika hukum, taraf sinkronisasi hukum, sejarah hukum, dan penelitian perbandingan hukum (Soekanto, 1981). Pendekatan penelitian yang digunakan adalah pendekatan perundang-undangan (statute approach) dan pendekatan konseptual (conceptual approach) (Marzuki, 2010). Penelitian ini didukung dengan bahan hukum primer berupa peraturan perundang-undangan yang berlaku dan bahan hukum sekunder berupa buku-buku hukum yang relevan dengan isu hukum serta bersifat deskriptif analitis. Teknik pengumpulan bahan hukumnya menggunakan dokumentasi. Teknik analisis bahan hukumnya menggunakan Teknik analisis isi (content analisys).

\section{Pembahasan}

\subsection{Membaca Globalisasi sebagai bagian dari Pelanggaran terhadap Hak-Hak Konsumen}

Kebutuhan perlindungan hak-hak asasi konsumen merupakan bagian dari konstruksi negara hukum. Disebutkan Alkostar (2000), bahwa konstruksi negara hukum menuntut ditegakkan tiang penyangga, penghormatan hak-hak asasi manusia, penyelenggaraan keadilan bagi seluruh rakyat dalam peradilan yang bebas.
Penghormatan hak asasi manusia (HAM) itu menjadi salah satu "ruh" yang menentukan konstruksi negara hukum. Ketika HAM ini dilanggar, maka identik dengan pelecehan terhadap martabat hidup bernegara dan pembenaran pelecehan harkat kemanusiaan.

Sikap konsumen di Indonesia terhadap suatu produk makanan dan minuman sangatlah sensitif (peka) dan reaksioner ketika produk makanan dan minuman yang dikonsumsinya atau beradar di tengah masyarakat ada indikasi tidak memenuhi standar sebagai produk makanan yang halal atau dibenarkan menurut ajaran agama dan norma yuridis yang berlaku. Sensitifitas ini juga membuktikan, bahwa konsumen mempunyai hak-hak asasi yang sebenarnya menuntut siapapun, khususnya kalangan produsen untuk menghormatinya.

Konsumen seperti itu merasa bahwa posisinya sebatas dijadikan menjadi objek ketika masih ada perusahaan atau produsen yang berani memproduk dan mengedarkan (menjual) makanan dan minuman yang tidak layak (tidak halal) menurut ajaran agama. Konsumen merasa bahwa hal ini termasuk pelanggaran terhadap hak-hak asasinya.

Kondisi kehidupan semakin maju, khususnya dalam kaitannya dengan teknologi produksi pangan, diduga ujian terhadap konsumen semakin besar. Hal demikian ini terkait diantaranya dengan perkembangan era globaliasasi, yang justru makin menempatkan posisi konsumen dalam posisi yang rawan (rentan) terhadap pengaruh-pengaruh buruk, dapat membahayakan diri, dan ajaran agamanya. Era globalisasi di satu sisi telah memberikan keuntungan bagi bangsa-bangsa di muka bumi, khususnya dalam memperoleh informasi tentang perkembangan kehidupan dan peradaban bangsa lain, namun di sisi lain, globalisasi telah menga-kibatkan dampak destruktif yang salah satunya dalam bentuk pelanggaran terhadap hakhak asasi manusia.

Dipaparkan Shihab (1997), dunia dewasa ini sedang diwarnai oleh global politics, global tech- 


\section{Jurnal Cakrawala Hukum, Volume 10 No. 2 Desember 2019}

ISSN PRINT 2356-4962 ISSN ONLINE 2598-6538

nology, global economy, global market, dan global strategy. Bahkan bumi tempat kita berada pun tidak terlepas dari prediket global, yakni global village. Walaupun globalisasi itu dinilai positip, bagi sementara pihak juga terkandung di dalamnya dimensi negatif. Sebagai contoh, ciri positip global market yang membawa peluang perluasan pasar dan keragaman konsumen, tetapi juga mengandung dimensi negatif dengan kerasnya kompetisi antar produsen di dunia. Sama halnya dengan arus informasi yang akurat dan cepat, bagi sementara pihak merupakan sarana infiltrasi kultural ideologis yang membawa dampak negatif terhadap nilai-nilai budaya setempat.

Paparan itu menunjukkan tentang kedahsyatan globalisasi dalam memberikan pengaruh terhadap kehidupan bangsa-bangsa di muka bumi. Pola berbudaya, berekenomi, membangun kekuatan politik dan berelasi sosial yang ditunjukkan bangsa lain dapat dengan mudah diserap dan diikuti oleh bangsa-bangsa lain di muka bumi. Arus informasi yang sangat cepat ini membuat masingmasing bangsa dapat dengan cepat dan mudah pula untuk melakukan perubahan-perubahan gaya hidupnya.

Negara-negara maju yang punya kekuatan ekonomi hebat dan menguasai jaringan persaingan di tingkat global baik secara langsung maupun tidak langsung merupakan pihak yang harus dituntut pertanggungjawabannya terhadap perubahan gaya hidup, khususnya di tingkat konsumsi atas produk makanan dan minuman. Sebab dari negara-negara maju ini, berbagai bentuk produk makanan dan minuman terus diekspor ke nagaranegara lain, tidak terkecuali negara-negara yang berpenduduk mayoritas muslim seperti Indonesia ini. Banyaknya jumlah penduduk ini merupakan objek pasar global.

Negara berpenduduk besar seperti Indonesia ini menjadi objek negara-negara maju yang saling berkompetisi untuk memperoleh keuntungan berlipat ganda. Berbagai bentuk produk makanan dan minuman serta lainnya diekspor ke Indonesia. Akibat derasnya ekspor makanan dan minuman itu, tingkat konsumsi atau gaya hidup rakyat Indonesia dengan mudah mengalami perubahan. Misalnya produk makanan dan minuman yang bermerk negara-negara asing sangat laku di pasaran (masyarakat Indonesia).

Akibat globalisasi di bidang makanan dan minuman yang mempengaruhi tingkat konsumsi rakyat Indonesia ini, negara-negara maju yang menjadi pengekspornya, ada dian-taranya yang tidak menjaga kualitas moral, etik atau kualifikasi barang yang diekspornya. Eksistensi agama yang dipeluk rakyat Indonesia tidak diperhitungkan.

Misalnya dalam kasus barang-barang yang berkaitan dengan makanan dan minuman, yang di negara asal (pengekspor) tidak layak dikonsumsi dan sudah termasuk kategori dibuang di keranjang sampah, juga di ekspor (dijual ke luar negeri) ke Indonesia atau negara-negara lain.

Sudah lama harian Kompas (26-27 September 1994, dalam Harwan, 2016) memberikan ulasan, dengan globalisasi rakyat akan mendapatkan produk barang/jasa yang terbaik dan para produsen Indonesia dipaksa mampu menghasilkan produkproduk berkualitas karena tuntutan kompetitif pasar dunia. Akan tetapi liberalisasi perdagangan akan dapat juga membawa bencana bagi Indonesia, apabila Indonesia tidak mempersiapkan diri dalam menghadapi suasana kompetitif pasar dunia. Indonesia akan menjadi mangsa empuk bagi negara-negara maju beserta para produsennya yang memanfaatkan liberalisasi perdagangan untuk mendominasi pasar domestik Indonesia.

Dengan kata lain, di tingkat global posisi konsumen Indonesia sangat rawan dalam menghadapi persaingan produsen yang memanfaatkan kondisi liberalisasi perdagangan. Di satu sisi konsumen Indonesia akan dihadapkan dengan berbagai bentuk dan macam produk yang dapat dipilihnya dengan bebas. namun di sisi lain, konsumen Indonesia juga dituntut untuk bisa membaca 


\section{Kedudukan Hak Konsumen dalam Memperoleh Informasi yang Jujur terhadap Produk Makanan dan Minuman \\ Bambang Satriya}

dan mencerna dengan jeli produk seperti makanan dan minuman yang dipilihnya, sebab bukan tidak mungkin produk atas barang yang dipilihnya tersebut kadar kehalalannnya diragukan dan dari segi kualitasnya juga rendah, bahkan mengancam (membahayakan) dari sudut keselamatan dan kesehatan.

\subsection{Hak Mendapatkan Informasi yang Jujur dikalahkan oleh Demagogisme Produsen}

Hak-hak konsumen kurang mendapatkan perhatian utama akibat kuatnya target keuntungan berlipat ganda yang diinginkan produsen (khususnya kalangan pemilik modal kuat), yang merasa dirinya tidak akan bisa dikalahkan oleh konsumen ketika terjadi sengketa atau gugatan hukum yang dengan konsumen. Perasaan berada dalam posisi kuat karena pemerintah sendiri lebih berpihak kepadanya telah mengakibatkan posisi tawar (bargaining position) konsumen semakin lemah.

Selama ini dapat terbaca, bahwa posisi konsumen di Indonesia adalah lemah dan pasrah terhadap pihak yang memberikan jasa, misalnya konsumen pasrah kepada dokter, dan petugas pelayanan kesehatan lainnya untuk mendapatkan obat yang dibutuhkan guna penyembuhan sakit dan penyakitnya. Namun perkembangannya dewasa ini Pemerintah telah lebih peduli terhadap kepentingan konsumen, terlihat dengan semakin disempurnakannya peraturan perundang-undangan yang diharapkan dapat melindungi konsumen, seperti dalam Undang-undang Kesehatan dan Undang-undang Konsumen, serta peraturan perundang-undangan lainnya.

Resolusi PBB mengenai Perlindungan Konsumen Tahun 1985 menyebutkan hak-hak konsumen terdiri atas: (1) hak atas keamanan dan keselamatan, (2) hak memilih, (3) hak untuk didengar pendapat dan keluhannya. (4) hak atas lingkungan hidup, dan (5) hak untuk mendapatkan informasi yang jujur.
Adanya hak konsumen yang kelima tersebut dengan tegas memberikan kedudukan terhadap konsumen berupa hak informasi seluas-luasnya dan bersifat jujur. Konsumen harus dilin-dungi dari informasi tentang barang/jasa yang bersifat menyesatkan atau menipu.

Dipihak lain dengan adanya hak itu sama artinya dengan memberi kewajiban kepada produsen, pengusaha, atau pemberi pelayanan jasa dalam menjalankan transaksinya harus terlebih dahulu memberi informasi yang benar. Pengusaha (produsen) yang bergerak baik berupa produk makanan dan minuman ataupun produk untuk dipakai atau digunakan biasa perlu dan wajib dalam setiap produk yang dipasarkannya memberi informasi yang benar.

Pengusaha makanan dan minuman terutama yang dikemas perlu memberi lebel atau tanda pada setiap produk yang dihasilkannya. Dalam hal kewajiban pemberian label, tidak terbatas hanya menyangkut produk yang dapat dimakan atau diminum. Semua produk yang dihasilkan, dan diedarkan kepada konsumen wajib diberi label.

Misalnya menurut ketentuan Pasal 22 UU No. 2 Tahun 1981 tentang Metrologi Legal ditentukan, bahwa semua barang dalam keadaan terbungkus yang diedarkan, dijual, ditawarkan, atau dipamerkan wajib diberitahukan, atau dinyatakan pada bungkus, atau pada labelnya dengan tulisan yang singkat, benar dan jelas mengenai a) Nama barang dalam bungkusan itu; b) Ukuran, isi, atau berat bersih barang dalam bungkus itu dengan satuan, atau lambang yang telah diakui oleh Konperensi Umum untuk ukuran, dan timbangan. c) Jumlah barang dalam bungku-san itu jika barang itu dijual dengan hitungan.

Jelas menurut ketentuan mengenai pelabelan itu, bahwa dalam pelabelan dirumuskan informasi seperti pencantuman kata, atau tanda halal yang menjamin bahwa makanan dan minuman diproduksi, dan diproses sesuai dengan persyaratan objektivitas, dan kelengkapan serta tidak menye- 


\section{Jurnal Cakrawala Hukum, Volume 10 No. 2 Desember 2019}

ISSN PRINT 2356-4962 ISSN ONLINE 2598-6538

satkan. Dalam tanda atau label harus pula dicantumkan nama dan alamat pabrik atau distributornya (Mustofa, 2015)

Label tidak boleh diberi keterangan yang dapat menyesatkan pembeli, baik mengenai isi maupun jumlah kandungannya. Tanda atau label yang tidak benar karena sengaja atau dipalsukan (dibuat-buat) digolongkan menyesatkan. Label harus jelas dan menyolok, informasi harus dalam bahasa nasional Indonesia, isinya harus jelas serta mudah dimengerti oleh konsumen pada waktu akan membeli dan saat menggunakan atau memakainya. Kewajiban produsen adalah mencantumkan label dan tanda pada produk suatu makanan dan minuman kemasan. Dengan kata lain suatu produk makanan dan minuman tidak boleh dijual dengan nama yang tidak sesuai dengan kandungan isi makanan/minuman tersebut. Misalnya dalam pabrik farmasi tidak boleh memberikan informasi ganda, yaitu keterangan tentang sesuatu obat yang berbeda kepada pihak yang berlainan. Sebagai komparasi saja misalnya kepada konsumen awam informasi kegunaan obat lebih ditonjolkan tetapi kurang memberikan informasi kontradisi, sedangkan kepada dokter secara jelas memberikan informasi kontradisi dari obat tersebut. Hal demikian suatu kesesatan yang bisa merugikan konsumen. Pencantuman label tersebut dimaksudkan agar masyarakat mendapat informasi yang benar tentang isi dan asal bahan yang dipakai, yang meliputi bahan pokok, bahan tambahan, dan tahun kadaluarsa, dimaksudkan agar barang yang bersangkutan digunakan sebelum tanggal bulan, dan tahun yang dicantumkan dalam label (Wahib, 2012).

Begitu pula dalam soal produk makanan dan minuman, pencantuman informasi yang jujur berupa labelisasi halal oleh perusahaan (produsen) yang sudah digariskan secara yuridis merupakan bagian dari jaminan perlindungan terhadap hak asasi konsumen yang seharusnya wajib dihormati.

Aspek hukum tersebut sebagai suatu indikasi tentang keinginan pemerintah dalam memberikan perlindungan terhadap konsumen. Bentuk perlindungan yang diberikan pemerintah ini difokuskan untuk menjamin keselamatan konsumen dari berbagai bentuk tindakan produsen yang tidak terpuji, menyesatkan dan membahayakan yang intinya merugikannya akibat ulah produsen yang semata-mata menjadikan konsumen sebagai objek perdagangan.

Melindungi konsumen menjadi kewajiban pemerintah untuk memperhatikannya sesuai dengan tujuan negara: melindungi segenap bangsa dan seluruh tumpah darah Indonesia.. Usaha yang dilakukan pemerintah sekarang ini dalam penanganan masalah konsumen, diantaranya melalui: pembinaan, pengawasan dan pengamanan. Misalnya di bidang pengawasan pelabelan hasil produksi, sesuai dengan ketentuan pada Pasal 21 ayat 2 UU No. 23 Tahun 1992 Tentang Kesehatan, yakni setiap hasil produksi terutama makanan/ minuman yang dikemas wajib diberi tanda atau label yang berisi; Bahan yang dipakai, komposisi setiap bahan, tanggal, bulan, dan tahun kedaluarsa, dan ketentuan-ketentuan lainnya.

Pasal 109 Undang-Undang Nomor 36 Tahun 2009 Tentang Kesehatan, bahwa setiap orang dan/ atau badan hukum yang memproduksi, mengolah, serta mendistribusikan makanan dan minuman yang diperlakukan sebagai makanan dan minuman hasil teknologi rekayasa genetik yang diedarkan harus menjamin agar aman bagi manusia, hewan yang dimakan manusia, dan lingkungan.

Pasal 110 menegaskan, bahwa setiap orang dan/atau badan hukum yang memproduksi dan mempromosikan produk makanan dan minuman dan/atau yang diperlakukan sebagai makanan dan minuman hasil olahan teknologi dilarang menggunakan kata-kata yang mengecoh dan/atau yang disertai klaim yang tidak dapat dibuktikan kebenarannya. 


\section{Kedudukan Hak Konsumen dalam Memperoleh Informasi yang Jujur terhadap Produk Makanan dan Minuman}

Bambang Satriya

Lebih teknis, digariskan Pasal 111

(1) Makanan dan minuman yang dipergunakan untuk masyarakat harus didasarkan pada standar dan/atau persyaratan kesehatan.

(2) Makanan dan minuman hanya dapat diedarkan setelah mendapat izin edar sesuai dengan ketentuan peraturan perundang-undangan.

(3) Setiap makanan dan minuman yang dikemas wajib diberi tanda atau label yang berisi: a. Nama produk; b. Daftar bahan yang digunakan; c. Berat bersih atau isi bersih; d. Nama dan alamat pihak yang memproduksi atau memasukan makanan dan minuman kedalam wilayah Indonesia; dan e. Tanggal, bulan dan tahun kadaluwarsa.

(4) Pemberian tanda atau label sebagaimana dimaksud pada ayat (1) harus dilakukan secara benar dan akurat.

(5) Ketentuan lebih lanjut mengenai tata cara pemberian label sebagaimana dimaksud pada ayat (3) dilakukan sesuai dengan ketentuan peraturan perundangundangan.

(6) Makanan dan minuman yang tidak memenuhi ketentuan standar, persyaratan kesehatan, dan/atau membahayakan kesehatan sebagaimana dimaksud pada ayat (1) dilarang untuk diedarkan, ditarik dari peredaran, dicabut izin edar dan disita untuk dimusnahkan sesuai dengan ketentuan peraturan perundang-undangan.

Ketentuan tersebut menunjukkan sebagai proteksi yang bersifat asasi terhadap konsumen. Konsumen dijaga atau dilindungi oleh norma yuridis supaya tidak dijadikan obyek permainan oleh pengusaha (produsen) atau korporasi yang lebih condong berburu keuntungan. Persyaratan yang cukup banyak terdahap produk pangan atau minuman yang boleh beredar menandakan bahwa para pelaku usaha berkewajiban menjaga kepercayaan yang diberikan oleh negara (melalui norma yuridis).

Pemberian tanda atau label dimaksudkan agar masyarakat mendapat informasi yang benar tentang isi dan asal bahan yang dipakai dalam rang yang akan dikonsumsikan tersebut, sehingga masyarakat mengerti apa yang harus diperbuat terhadap barang yang akan dikonsumsikan iitu. Begitu pula halnya dengan pencantuman tandatanda lainnya seperti, tanda halal ini dilakukan untuk menjamin bahwa barang tersebut diproduksi sesuai dengan persyaratan makanan halal, sehingga masyarakat tidak salah mengkonsumsinya, terutama bagi ummat Islam. Misalnya lagi berkaitan dengan pemasaran yang tidak sedikit diantaranya terjadi praktik-praktik pmberian informasi yang tidak jujur. Padahal sudah jelas bahwa maksud dari produksi suatu barang atau jasa adalah untuk dikonsumsi oleh mereka yang membutuhkannya. Produsen bertindak untuk mendekatkan produknya kepada konsumen, dengan cara mengedarkannya di pasaran. (Wahib, 2012)

Pengedaran terhadap barang dan jasa, khususnya yang berhubungan dengan promosi, dan pemasaran mempunyai sering bertabrakan dengan hak-hak konsumen, yaitu hak konsumen atas informasi yang jujur dan hak untuk memilih. Adanya tabrakan kepentingan ini sering menimbulkan kerugian, terutama konsumen yang kebanyakan posisinya sangat lemah dibandingkan para produsen.

Keadaan demikian itu mewajibkan pemerintah (negara) untuk mengimplementasikan perangkat hukumnya untuk melindungi kedudukan konsumen yang lemah itu. Tindakan pemerintah ini perlu didukung dengan cara terjun langsung ke lapangan untuk mengatasi masalah pemasaran dan praktek perdagangan yang merugikan konsumen, melalui pengawasan dan tindakan yang tegas dan adil. Terjun langsung ini bisa dibuat lebih teknis sebagai wujud implementasi kebijakannya. O’Toole dalam Raj Paudel (2009) menyebut implementasi kebijakan publik berikut: as what develops between the establishment of an apparent intention on the part of government to do something or stop doing 


\section{Jurnal Cakrawala Hukum, Volume 10 No. 2 Desember 2019}

ISSN PRINT 2356-4962 ISSN ONLINE 2598-6538

something and the ultimate impact of world of actions. More concisely, he remarks that policy implementation refers to the connection between the expression of governmental intention and actual result atau seperti apa yang berkembang antara pembentukan tujuan yang jelas pada bagian dari pemerintah untuk melakukan sesuatu atau berhenti melakukan sesuatu dan dampak akhir dari tindakan dunia. Lebih singkat, ia menyatakan bahwa implementasi kebijakan (pembangunan) mengacu pada hubungan antara pernyataan tujuan pemerintah dan hasil aktual.

Kelemahan secara general selama ini terletak di pengawasan terhadap produk pangan atau minuman yang beredar, sehingga secara tidak langsung memberikan kesempatan kepada pelaku usaha atau produsen dalam menikmati kebebasan dalam menjalankan aktifitas bisnisnya, sehingga dari sinilah kemungkinan pelanggaran hukum mudah terjadi.

Pengawasan terhadap pemasaran dan promosi barang dan jasa, negara perlu bertindak secara obyektif, yaitu dengan mewajibkan para pelaku pemasaran untuk memiliki suatu kode etik pemasaran dan promosi, penentuan standar pemasaran dan promosi yang menjamin terciptanya pemasaran dan promosi yang jujur, serta bisniis yang adil, sehingga apabila pihak produsen melakukan pelanggaran terhadap ketentuan yang berlaku tersebut, maka pemerintah dapat mengambil tindakan-tindakan yang diperlukan untuk menjamin perlindungan terhadap pelanggan atau konsumen supaya masyarakat (konsumen) tidak merasa dirugikan.

Contoh promosi yang sering merugikan konsumen adalah promosi lewat periklanan yang sangat persuasip, berlebih-lebihan dan bahkan sering bersifat curang dan menipu. Informasi yang disalurkan lewat promosi yang mengandung unsur penipuan jelas tidak memberikan informasi yang benar terhadap konsumen sehingga konsumen dirugikan karena haknya dilanggar. Bentuk promosi demikian dapatlah dikategorikan sebagai suatu bentuk kejahatan.
Meskipun sudah berlaku Undang-Undang Nomor 23 Tahun 1992 tentang Kesehatan, namun tampaknya fenomena-fenomena yang ada kaitannya dengan perlindungan konsumen belumlah menggembirakan. Cukup banyak ditemukan kasuskasus produksi atas barang makanan dan minuman yang kadaluwarsa, tidak layak dengan standar (kualifikasi) kesehatan dan mengandung unsur penipuan atau pembohongan atas konsumen. Hak konsumen untuk memperoleh informasi yang jujur diabaikan (diingkari).

Atas dasar pertimbangan kepentingan konsumen yang faktanya seringkali diabaikan oleh produsesn itulah barangkali yang menjadi alasan sosial-politik bagi pemerintah untuk lebih kuat memberikan dukungan yuridis terhadap hak-hak konsumen. Hal ini dapat dibaca dengan kehadiran Undang-undang Nomor 8 Tahun 1999 tentang Perlindungan Konsumen.

Hal itu dapat dibaca dalam salah satu konsideran UU Nomor 8 Tahun 1999 tentang Perlindungan Konsumen menyebutkan, bahwa semakin terbukanya pasar nasional sebagai akibat dari proses globalisasi ekonomi harus tetap menjamin peningkatan kesejahteraan masyarakat serta kepastian atas mutu, jumlah dan keamanan barang-barang atau jasa yang diperoleh di pasar.

Tuntutan moral adanya perlindungan terhadap konsumen dari berbagai kerugian karena faktor ketidakpastian mutu dan jumlah yang tidak jelas, dan ketidak-amanan barang atau jasa yang diperoleh konsumen di pasar, terutama dalam era demokrasi ekonomi dan globalisasi, menjadi bagian dari dasar moral pertimbangan dikeluarkannya Undang-undang Nomor 8 Tahun 1999. Dibukanya lorong hukum bagi konsumen untuk mengimplementasikan hak-haknya oleh Undangundang Nomor 8 Tahun 1999 merupakan indikator dari masyarakat bangsa Indonesia untuk melindungi kepentingan konsumen secara yuridis (Alkostar, 2000) 


\section{Kedudukan Hak Konsumen dalam Memperoleh Informasi yang Jujur terhadap Produk Makanan dan Minuman \\ Bambang Satriya}

Hak kepastian atas mutu suatu barang seperti dalam Undang-undang Konsumen itu, antara lain dapat dibaca melalui informasi yang diberikan oleh produsen, baik melalui iklan di media massa maupun informasi langsung dalam kemasan barang itu. Jika antara informasi yang ada dengan kenyataannya terjadi pertentangan atau tidak ada kebenarannya atau mengandung "cacat obyektifitas", maka hal itu berarti konsumen dirampas hak untuk mendapatkan informasi yang jujur, atau konsumen dapat diposisikan sebagai korban pelanggaran HAM.

Pasal 9 Undang-Undang Nomor 39 Tahun 1999 tentang Hak Asasi Manusia disebutkan, bahwa setiap orang berhak untuk hidup, mempertahankan hidup dan meningkatkan taraf kehidupannya. Kalau produk makanan dan minuman mengakibatkan konsumen berpenyakitan atau merusak kesehatannya, maka praktik demikian dapat dikategorikan sebagai bentuk pelanggaran terhadap hak kesehatan atau kondisi yang mendukung pengembangan taraf hidupnya.

\section{Simpulan}

Konsumen belum menjadi raja. Konsumen ini masih seringkali ditempatkan dalam posisi yang lemah oleh kalangan pelaku usaha atau produsen makanan dan minuman. Penempatan demikian ini mengakibatkan problem serius yang membahayakan kesehatan dan keselamatan konsumen Indonesia. Hak untuk memperoleh informasi yang jujur atas suatu produk makanan dan minuman yang seharusnya diterima oleh konsumen ternyata masih menjadi hak yang sulit dinikmati, karena faktanya banyak pelaku usaha atau produsen baik di tingkat lokal, nasional, maupun global yang melanggarnya.

Konsumen masih menjadi obyek yang dirugikan atau sekedar dijadikan target untuk memburu keuntungan ekonomi. Akibatnya, dari hak informasi yang dilanggar ini, hak konsumen lainnya seperti kesehatan dan keselamatannya dirugikannya. Pelanggaran HAM yang tergolong serius terhadap konsumen ini tidak bisa diabaikan oleh pemerintah (negara). Produk yuridis yang dinilai sudah memadai (representatif) haruslah diikuti dengan langkah konkritnya dalam implementasi secara konsisten.

\section{Daftar pustaka}

Alkostar, Artijo. 2000. Negara Tanpa Hukum, Catatan Pengacara Jalanan. Yogyakarta. Pustaka Pelajar.

Harwan, Amir. 2016. Globalisasasi: Ujian Kehalalan Produksi Pangan Dunia. Surabaya. Himapres.

Marzuki, Peter Mahmud. 2010. Penelitian Hukum. Jakarta. Prenada Media Group.

Shihab, Alwi. 1997. Islam Inklusif. Bandung. Mizan. Mustofa. 2015. Ancaman Serius terhadap Globalisasi Pangan terhadap Masyarakat Muslim. Surabaya. Visipres Media.

Raj Paudel, Narendra. 2009. A Critical Account of Policy Implementation Theories: Status and Reconsideration. Nepalese Journal of Public Policy and Governance. xxv (2) Desember.

Soekanto, Soerjono. 1981. Pengantar Penelitian Hukum. Jakarta. UI Press.

Undang-Undang Republik Indonesia Nomor 2 Tahun 1981 Tentang Metrologi Legal.

Undang-Undang Republik Indonesia Nomor 23 Tahun 1992 Tentang Kesehatan.

Undang-Undang Repub.Lik Indonesia Nomor Nomor 39 Tahun 1999 Tentang Hak Asasi Manusia.

Undang-Undang Republik Indonesia Nomor 36 Tahun 2009 Tentang Kesehatan.

Undang-Undang Republik Indonesia Nomor 8 Tahun 1999 Tentang Perlindungan Konsumen.

Wahib. Moh, 2012. Labelisasi Halal Sebagai Perlindungan terhadap Hak Asasi Konsumen (Perspektif Hukum Islam dan Positip). Surabaya. Visipress Media.

Wahid, Abdul. dkk,. 2017. Penegakan Kode Etik Profesi Notaris. Jakarta. Nirmana Media Utama. 